\title{
Europæeren i Europas spejl
}

\author{
LARS S. ARNDAL
}

Tørhed i munden ... smag af gammel aske ... sjusser ... sved ... hvor? hvorfor? Du er på et hotelværelse et sted i Europa ... du har drømt i din urolige søvn ... du vil glemme det.

Jeg siger: du må ikke glemme det .... lad vandglasset stå ... lad dig glide tilbage men hold fast $\mathrm{i}$ bevidstheden. Du er på hotelværelset i Europa, men du glider tilbage i tiden til drømmen, hun træder frem for dig - hold fast; se hende. I kroppen på dig dæmrer det: synet af hende og længslen, et begær; du er fascineret, revet med. Du vil have hende, men ved at du må tage hende for at få hende. Du kan ikke være dig selv, du må forandre dig, lade dyret vokse frem ... så husker du igen: drømmen har du drømt tidligere ...

Hun ser til dig, leger med dig, og du foregiver at gå med i legen uskyldighed; længere og længere væk kommer I ... og så har du hende. Du har taget Europa til dig, men du har båret bedragets maske for at få hende med dig; du har betvunget hende, for kun sådan kunne du få hende. Nu forstår du sveden, der atter gør lagnerne klamme: du måtte tage hende med magt; angsten for din egen syge fantasi om at besidde hende; gør søvnen urolig. Du vil ikke men må gøre det igen og igen, på samme måde som du drømmer drømmen igen og igen.

Du er på hotelværelset i Europa; du vil væk fra Europa...

Europas fødsel - som kontinent eller som tanke - kan dateres på mange måder: med oplysningsideens fremvækst og dens hævdelse af det selvberoende indvid; med trykkekunstens udnyttelse af et alfabet, der lader tanken udvikle sig lineært; med det kopernikanske verdensbillede eller med sammensmeltningen af 
hellenistisk og jødisk tænkning i forbindelse med kristendommens knæsættelse som fælles etisk og kulturelt grundlag. Eller man tager mere håndfaste historiske fakta i brug: slaget ved Salamis $480 \mathrm{f}$. Kr., hvor den Athenske kultur sejrer over de barbariske persere; Maruerne, der smides ud af Spanien 1492, eller jerntæppet, der trækkes ned gennem Europa efter 2. Verdenskrig.

Et fælles træk gør sig dog gældende i alle varianterne, og viser sig også i en af de ældste overleveringer om Europas tilblivelse: Europa bliver til i en bemægtigelse og en afgrænsning. Myten om Zeus, der begærer den fønikiske princessse, Europa, rummer $\mathrm{i}$ al sin enkelthed en række af de dilemmaer, der har hjemsøgt Europa og gjort det til uroens kontinent. Zeus er Europæeren, der er blevet besat ved synet af det fremmede; han drager til Fønikien, forvandler sig til en tyr og lokker Europa længere og længere ud på havet, indtil hun ikke har nogen chance for at vende tilbage. Han bortfører Europa, men fører hende samtidig over til den verdensdel, der kommer til at tage navn efter hende.

Myten om ranet af Europa fortæller mindst tre ting: For det første, at Europa først bliver synlig uden for Europa. For det andet, at Europæeren må gennemgå en metamorfose for overhovedet at blive i stand til at træde i forhold til Europa. For det tredje, at Europa skal bemægtiges, underlægges ved hjælp af list; Europa kommer os ikke i umiddelbart i møde, men gemmer sig på andre kontinenter.

\section{Historien til hest}

Han har lige rejst sig fra-skrivebordet i Jena for at slappe af fra det store arbejde. Han begiver sig ud i gaderne og pludselig sker der noget: en særlig uro, en mumlen i mængden, en bevægelse, og så kommer de franske soldater ridende med kejsergeneralen i spidsen. Året er 1806, preusserne just besejret og tilskueren Hegel farer hjem for at notere "I dag så jeg verdensånden til hest".

Det moderne Europa fødes med tanken om beherskelsen af historien. I mødet mellem den tænkende Hegel og den handlende Napoléon viser den europæiske historiske tanke sine to sider: historien er på den ene side et fremadrettet projekt, som Eu- 
ropæeren kan gribe ind i og kontrollere; en forestilling om, at historien er blevet overleveret til nutiden med en forpligtelse til at bruge den for fremtidens skyld. På den anden side skuer Europæeren bagud i historien og gør sig til herre over fortiden; alle historiens begivenheder får i forklaringens skær en betydning, der ophæver dem fra tørre historiske events til at være led i en større plan. I sin kyniske bemærkning om, at de fredelige tider er tomme sider $\mathrm{i}$ historiens store bog rammer Hegel præcist denne forestilling: historien vrimler med ofre, men ingen af dem er nyttesløse - alle er de bragt for at føre kontinentet frem til den tinde, der nu skal være udgangspunkt for menneskets nye og bedre historie.

Men det hører til denne fortællings paradoks - og er vel egentlig dens blindhed - at den ikke ser, at man med afsæt fra et absolut højdepunkt kun kan bevæge sig én vej, når man bevæger sig fremad - og det er nedad igen. Historiens egen ironiske kommentar til Europæerens optimisme kom i form af et par krige, der lynhurtig har dækket hele det historiske projekt til med døde kroppe og sultende mennesker i ruiner. Som en dementi af forestillingen om overskuelighed og retning valgte historien at præsentere Europæeren for en gentagelse af fortidens grusomheder - blot med øget intensitet: Auswitsch og Gulag-øhavet; Balkans danse-macabre. Som om historien ønsker at skrige Europæeren op ved st gøre sine metoder endnu mere skingre, dens farver endnu mere skrigende.

Francis Fukuyamas diagnostik af den europæiske tilstand efter murens fald kommer alt for sent. Historien havde længe inden nået sin afslutning, men på en mere uhyggelig vis: Afslutningen på historien udmønter sig ikke i den evige fred og global konsensus. Historien udviser en påfaldende stabilitet, men ikke i form af en harmonisk stilstand, der tillader Europæeren at vende tilbage til sin drømte urtilstand. Stabiliteten er derimod historiens tomgang, dens gentagelser, der ikke tillader Europæeren at bryde ud af det mønster, der forlængst er lagt ned over Europakortet. Et mønster, som Europæeren på sine rejser finder i Flandern, langs Rhinen, ved Verdun, hvor der ligger lag på lag af slag, 
af frontlinjer, der er flyttet frem og tilbage gennem landskabet, men som aldrig har flyttet Europa.

Måske er dette den første grund til vanskeligheden ved at nærme sig Europa: bestræbelserne på at samle historien, krones ikke med held men med vildløb i blindgyder; historien dækkes til af kød og blod.

\section{Europæeren}

I et italiensk landskab spækket med ruiner, med sydens blomster og klar himmel ligger en ædel type, svøbt i kappe og med Merkurhat. Han skuer ud: rolig, besindig. Han er væk hjemmefra, men er faldet til i et landskab, der formeligt bøjer sig under hans blik. Ruinerne truer ham ikke, men er det leje, hvorfra han kan betragte verden og samle den i sine tanker. Selv kommenterer han: „dette billede er for stort til vores nordiske boliger". Prototype på Europæeren er denne selviscenesatte Goethe fra dannelsesrejsens tid. En prototype, fordi han i ét greb skaber myten om en europæisk enhedskultur, der rækker sine lange arme tilbage i historien og ud over hele kontinentet. Forskellene i kultur og forskellene frembragt af de historiske afstande, der manifesterer sig i ruinerne, er ikke et problem, snarere selve programmet: forskellene gør det meningsfuldt at rejse rundt, fordi Europæeren kan lære sig selv bedre at kende gennem de andre.

Men i sidste instans skal han holde det hele i sig egen hånd: have det store greb, der forener det kølige med det temperamentsfulde; det kaotiske med det ordnede; det sjælelige med det kropslige; det eget med det fremmede. Europæeren vokser frem som et universelt menneske. En legemliggørelse af den meningsfulde historie: Europæeren skal spænde over hele kontinentet og over hele historien, og denne idealiserede skikkelse skal bringe løsningen på Europas konflikter.

Paradoksalt nok er Europæeren i denne skikkelse atter dukket op i antidannelséns tidsalder - måske som et sidste forsøg på en redning af den europæiske tanke. Den intellektuelle, der rejser Europa tyndt for at finde frem til det europæiske, er atter på scenen. Som antropolog, som kulturforsker, eller i skikkelse af litteraten, der trækker de store linjer - Hans Magnus Enzensberger, 
Claudio Magris, Peter Esterhazy. Men Enzensbergers tourd'Europe bliver til en patetisk arkaisk gestus, hvor forfatteren optræder som omvandrende Voltaire-citat med encyklopædisk viden om både nord og syd og øst og vest. En flov gestus, som ironisk slår ned i titlen på hans værk: Ach Europa! Et udtryk for at forsøget på at samle billederne kun er lykkedes i form af omslagets postulat. Magris endnu mere desperat, fordi han par-tout vil tvinge Donaus snart trætte løb til endnu engang at løfte hele Centraleuropa. En tur ad Donau, der i sig selv skal give læseren forestillingen om, at dette hænger sammen blot fordi Donau løber gennem centraleuropas lande: det geografiske faktum ophævet til kulturhistorisk mytologi. Esterházy mere prøvende og legende, men dog endnu som en intellektuel præstation: fortælleren står bag det hele og disker op med henvisninger og referencer, historiske allusioner og hverdagsagtige fakta blot for med sin egen legende men overlegne gestus at samle billedet i bogen.

Fælles for disse tre er, at de ikke har set, hvordan Europæeren allerede er blevet til realitet. Bag om ryggen på de intellektuelles bestræbelser på at skabe den store kulturelle konstruktion Europa har Europæeren indfundet sig: det universelle menneske, verdensborgeren er trådt frem på scenen. Men når den intellektuelle stadig sentimentalt kan drømme om Europæeren, er det fordi, den realiserede Europæer ikke er et produkt af den intellektuelles konstruktionstrang.

Man møder ham overalt i Europa, altid optaget, dannet og interesseret. Han behersker mindst to-tre af hovedsprogene og har derfor travlt med at bladre sig igennem Le Monde, Die Zeit og The Guardian for at følge med i de nyeste udstillinger eller for at se, hvilken by der i næste ombæring skal agere Europæisk kulturby, skal lægge ryg til en biennale eller endnu en verdensudstiling. Ellers er han svær at sige noget om, for man ser ham kun i glimt, når han haster gennem udstillingshallerne med kunst, der er degenereret til kulturprodukt. En massiv ophobning: kunsten på den ene side og menneskene, der skal se den, på den anden. Kunsten i form af store spektakulære begivenheder, der giver Europæeren chancen for denne ene gang at se lige det billede af Cézanne eller Rembrandt, som ellers hænger afsondret $i$ en 
amerikansk villa. Akkurat dette billede denne gang, og så næste uge i den næste storby akkurat dette billede, og ugen efter endnu et. Menneskene, som hobe af billedglade (lalleglade) kulturister, der sidder dampende $\mathrm{i}$ airconditionerede busser på vej til det næste museum med den eneste ene Mona Lisa. Europæeren har set det meste og skal nå at se det hele, men han kan ikke skelne længere, det blaserete vokser i ham for hver gang han møder et nyt højdepunkt.

Eller han ser noget anderledes ud. Så træffer man ham på motorvejens rasteplads. Som sydtysker på vej til den svenske skærgård eller som dansker på vej til den franske riviéra - altid på vej et andet sted hen. Sproget kan han måske ikke så meget af, men han kender det nye lingva franka udformet som musikvideoer, quiz-programmer eller drejende lykkehjul. Kan man ikke lige se programmet hjemmefra skal man nok kunne finde det identiske på den lokale kanal. Og alt med en egen æstetik, der dog er den samme: reklameæstetik, TV-æstetik osv. Kulturen ophøjes til kunst, men kunst uden modhager.

Europæeren boltrer sig i kunsten og boltrer sig i kulturen; han realiserer Schillers ideal om det æstetisk opdragede menneske, der har kunsten som område for den fri udfoldelse: Her er han hverdagsæstetikeren, kulturhedonisten udstillingsdyret. Frankrig, England, Tyskland, Rumænien? det er ét fedt, for han foretager sig det samme, hvor han end bevæger sig hen. Sattelitantenne på toppen af autocamperen, som fast forankringspunkt på turene ad Europas landevejsnet. Men det er en grotesk forvrængning: kunsten som frit område er forvandlet til kunsten som fritidsområde; det universelle menneske er blevet til det uniformerede menneske; han forsvinder bag sin egen maske. Måske er det den anden grund til Europas vaklen: Europæeren kan realisere sig selv, men når han gør det udhuler han sig selv.

Derfor er det så vanskeligt at nærme sig Europa indefra. Først på når man bevæger sig uden for, eller når man bevæger sig på periferien kan man se det europæiske. Hvis Europæeren kan krænge historien som projekt af sig, hvis han kan lægge sin europæiserede standard til side, har han måske en mulighed for at se sig selv. Hvor verden mister selvfølgelighed og træder frem i pro- 
fileret form bliver Europæeren rystet og får sanserne tilbage. Europæeren kan vælge at miste sig selv og at glemme sin historie så begynder han at forstå sig selv.

\section{Periferien}

En landing i Tallinns lufthavn er en hudafskrabning: idet flyet slår ned på cementens ujævnhed flåes de sidste lag af tilbagelænet catering-tilfredhed af kroppen. Simulakrenes æsteticisme er lagt bagud som en vag erindring om om hektiske indkøb af flygtige parfurmer og glitrende magasiner i lufthavnen. Man har kun fløjet godt en time, men rammes af et stedsbestemt jet-lag. Europæeren er forrykket - geografisk, men rejsen i rum har også været en rejse i tid. Her er Europa kun synligt som et forlorent ansigt, der lægger sig over en alt for penetrant realitet: Kvinderne er legemliggjorte udsnit af halvtredsernes modeblade: affarvet hår fastholdt af hårlak, cyklamefarvet læbestift, ultrakorte skørter i tyve graders kulde; idealerne ligger lige for, men i forsøget på at blive europæiseret tager fantasierne overhånd og sminken ligger sig som en tyk, men gennemskuelig maske over den gamle identitet, der stadig gør sig gældende. På restauranterne en allestedsværende rytme af europæiske slagere, der skal foregøgle gæsten, at stedet allerede er blevet en del af det europæiske selvom tallerkenerne stadig er skårede og bærer indskriften „Restoran" - på russisk.

Europæeren bliver hensat til scenografien i et absurd drama: rummmenes elementer har allerede tabt enhver meningsfuld forbindelse med tiden; tingene råber til hinanden uden at kunne etablerer forbindelser over den tidsafgrund, der adskiller dem. Alt ligner i den grad det europæeren kommer fra, men igen og igen dukker detaljer op, der giver en skævvridning.

Europæeren kigger ud gennem ruderne og ser stiliseringen af de europæiske idealer, og han ser, hvordan menneskene, der går forbi vindueme, vrides ud af form - det ene sekund en gevaldig lang hovedskal; det næste sekund slangeformede knæ; derefter en arm, der i et ryk bliver til ét med kroppen, som den egentlig hører til. Er europæeren smittet af denne skæve verden, så absurditeten har sat sig fast? Er blikket blevet usikkert og famlende? 
Hvad sker der, spørge Europæeren før den banalt fysiske sandhed går op for ham: som alt andet i denne verden er også vinduesruderne behæftet med en lille fejl. Støbningen har været lige så ujævn som alt andet i den planlagte produktion, og derfor er der lige her i stuen indlagt et vidnesbyrd om en verden, hvor alt formet samtidig er ude af form. Verden fremtræder som i en spejlsal, hvor intet helt er hvad det giver sig ud for, men hvor man alligvel ser sig selv.

På den måde bliver vinduet også spejlkabinet for Europæeren: pludselig ser han, hvordan den polerede vesteuropæiske standard fjerner det urovækkende - det labile. Europæeren forstår hvordan hans verden er normaliseret og afrettet, ser hvordan de lige veje og de lette løsninger har gjort hans verden så nem at indtage, at han næste ikke registrerer det. Den europæiske facades umiddelbare gennemsigtig bliver til billede på faren ved det europæiskes gennemsigtighed: risikoen for at løbe lige ind i glasfacaden uden at have set den.

\section{Give me back the Berlinwall}

1. scene: Berlin er gentagelsens sted: Indstigningen foregår på Friedrichstraße, endnu en gang er det turen til Berlin Zoo han har foran sig. En rejse der næppe kan tage mere end to-tre minuttersådan huskes den i hvertfald. Ud af vinduet følger han banen; han ser stadig de tilmurede vinduer, der ligger som billeder på en stat, der lukkede sine øjne for det udenfor - men også som billeder på det man ikke kunne nærme sig. Genkendende glider blikket rundt, men noget mangler. Han ved, at det skal mangle og at det er godt, at det ikke er der længere, men Berlin er ikke Berlin uden dette. Midt i Berlin en slående tomhed, der også gør rejsen længere. Han falder ned i hullet og begriber ikke, hvordan denne tidligere så korte rejse kan være så længe; hvorfra tomheden kommer.

Muren er borte, forskellen forsvundet, og tiden strækker sig, indtil øjnene rammer et område med store tilsneede bunker af cement. Nybyggeri? spørger han sig selv, erobringen af Potzdammer Platz? I næste sekund forsvinder tomheden: Han forstår, at dér ligger muren. Her er grænsen, der satte forskellen. Men nu 
ligger den i bunker af murbrokker en slagge-grænse mellem nu'et og en historie, der efter kun fire år er så langt væk, at den ikke er en del af hans verden. Kun som tom gestus har den værdi: som et bevis på, at selv dette historiske moment med ét mister sin betydning. Ikke engang som souvenir i boderne omkring Brandenburger Tor har den kunnet bruges - dertil er der for meget af den.

Berlin står for Europæeren som billede på et af de højt besungne historiske omsving, men paradoksalt vidner byen om, hvordan historien ophæver sig selv. Muren jævnes med- jorden, en historisk dag. Men dagen efter er det glemt; med historisk effektivitet er ruinerne stuvet til side. Færdes man gennem byen og holder blikket ved det nederste af facaderne er nuancerne borte. Tidligere kunne øst og vest identificeres øjeblikkeligt: i øst som farveløse vægge, ramponerede døre, i vest alene i kraft af farverigdommen. Men nu er facaderne behersket af de samme reklamer, cafeerne af det samme interior. Kun gamle lysreklamer på toppen af husene, der gør opmærksom på en for længst nedlagt kolkhoses produkter, vidner om en historie, der snart ikke skal fortælles længere.

2. scene: De står sammensmeltede i et stort tungekys, pressede mod hinanden med vidtåben mund og øjnene lukkede; de er iklædt mørke jakkesæt men har smidt grænserne væk og er forende i et vampet broderskab. Men de er forstende - de to mænd; fossiler i enhver forstand. Historiske levninge fastholdt i en stor ironisk gestus: det broderlige, internationale kys forvandlet til historisk nekrofili. Man får det smidt i hovedet i form af et billede på vel en tre gange seks meter, hvor Bresjnev og Honnecker er fastfrosset på et stykke af Berlinmuren, der kun lige akkurat har overlevet her i udkanten af byens centrum.

Som ironisk gestus er billedet i én forstand indlysende: det viser magtens mænd i kødeligt fællesskab udstillet på det bygningsværk, der mest af alt viste delingens perversion i Europa efter anden verdenskrig. Men èr der ikke også en mere tildækket ironi ved at billedet er malet på den rest af muren, man har valgt at lade stå tilbage en af de mest ydmyge og yderster bydele? Kan billedet ikke samtidig være en ironisk kommentar til den nye 
myte om Europas enhed? Hvis murens fald står som billede på det spaltede Europa, der nu omsider skal samles og blive ét, så bliver konserveringen af det falske fællesskab på dette billede til en besk understregning af, hvordan også det nye fællesskab er bygget på en mesalliance.

I så fald forstår, man hvorfor Berlinerne ikke har ladet muren stå tilbage centralt på Potsdammer Platz; hvorfor historiens ruiner er forvist til denne afsides liggende grund: Berlineren vil ikke være det man gør ham til: han ønsker ikke at fremstå som det evige billede på denne nye verden, der skal vokse frem af anden Verdenskrigs sene gløder. Berlineren vil glemme, og han overlader det trygt til Europæeren endnu en gang at danse på Bastillens ruiner. Nietzsches ideal er blevet til realitet: her glemmes historien.

\section{Sontag bloody Sontag}

Så forstår man, hvorfor Europa på sine gamle dage ler så hæsligt til os: den historiske ruin er ikke nogen biomstændighed ved Europas historie men det fundament som Europæeren er henvist til at bygge på: skrøbeligt i sin natur, fordi det altid allerede er krakeleret, porøst. Når historiens dødningehoveder ler til Europæeren, er det fordi han skal vide, at han ikke kan bemægtige sig denne historie. Derfor vågner Europæeren i desperation og med sved på panden, når han på hotellet i Europa drømmer om Europa: han har set umuligheden af at indfri sit eget ideal; at han vil gå i opløsning i mødet med Europa.

Tilbage er der kun at gøre som Benjamins historiske engel: at vende ryggen til den historie, der ligger foran og kigge tilbage på ruinerne. Europæeren må konfrontere sig med brutaliteten og træde frem som Europæer i en selvmodsigende gestus, hvor han holder fast i drømmens afskyvækkende dimensioner.

Iscenesættelsen af Becketts Godot, som Susan Sontag til forargelse gennemførte i Sarajevo trods mortérregn og lig i gaderne, kan stå som et rammende billede på denne gestus. Stykket sætter som bekendt tiden ud af kraft: personerne handler, men deres handlinger forbliver uden konsekvenser. Som Europæeren, der selvbedragerisk mener at kunne bidrage til drømmens realise- 
ring, slår figurerne i Becketts stykke i tidens store dyne. Men intet forandres. Og dog er historien der: på scenen som rekvisitter fra en overvundet tidsalder og i figurerne som en svag men altafgørende erindring om Godot, der snart skal dukke op og forandre alt. Historien er der, men den er ikke deres. Adgangen til den er lukket - ikke fordi den er lukket bag dem, men fordi den har lukket sig om dem.

Drømmen om Europa kapsler Europæeren og historien inde. Drømmen udfolder sig i to mulige scenarier, men der er ingen mulighed for at vælge mellem dem. Begge viser, hvordan Europa vil bukke under for sig selv, gå til i et upåagtet selvmord. I det ene scenarie går drømmen op Europa i opfyldelse. Det sammenhængende kontinent, den fælles kultur virkeliggøres; Europæeren har bemægtiget sig sin verden, hans historie hænger sammen og danner et hele. Men i takt med dette projekts fremadskriden undergraver det sit eget fundament: det udsletter de forskelle, der skulle være elementer i helheden. Europæeren kan ikke se sig selv, fordi han overalt møder det samme.

I det andet scenarie mislykkes Europa, drømmen virkeliggøres som mareridt; forskellene sætter sig igennem på samme måde som Europæeren har set det tidligere. Forsøgene på at skabe enhed, munder paradoksalt i at forskellene vokser og fører til det europæiske barbari. Europa bliver ved med at være, hvad det altid har været: forskellenes sted, kampenes sted; Europæeren ser sig selv i øjnene og ser: drømmebilledet af sig selv i mødet med den anden.

Tartu, maj 96 


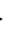

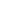

